\title{
Placental polyp: a rare cause of iron deficiency anemia
}

\author{
Fernando Peixoto Ferraz de Camposa , Ricardo Santos Simões $^{\mathrm{b}}$, \\ Aloísio Felipe-Silvac ${ }^{c}$ Milena Degaspari Gonzales ${ }^{b}$, Eder Nisi lláriob
}

Campos FPF, Simões RS, Felipe-Silva A, Gonzales MD, llário EN. Placental polyp: a rare cause of iron deficiency anemia. Autopsy Case Rep [Internet]. 2011;1(4):51-56. http://dx.doi.org/10.4322/acr.2011.017

\section{ABSTRACT}

\begin{abstract}
Placental polyps are defined as pedunculated or polypoid fragments of placenta or ovular membranes retained for an indefinite period of time into the uterus after abortion or child birth. An important cause of retention is placental accretism, an abnormal adherence of the placenta into the uterine wall. Chronic cases are rarely reported in the literature. In these cases, the placental retention in the immediate postpartum is not followed by heavy bleeding what makes the diagnosis challenging. We report a rare case of iron-deficiency anemia in a multiparous 29-year-old female patient two years after the last delivery. She sought medical care with clinical symptoms of anemia and recent menses alterations. There was no history of abortion. On gynecological examination, there was a twofold enlarged uterus, and the pelvic ultrasound revealed an image compatible with an endometrial polyp. She underwent open hysterectomy because of uncontrollable bleeding followed by hypotension after curettage. The histolopathologic examination revealed a partially hyalinized and necrotic placental polyp.
\end{abstract}

Keywords: Iron deficiency; Anemia; Uterine hemorrhage; Placenta accreta; Hysterectomy.

\section{CASE REPORT}

A 29-years-old, previously healthy, female patient sought medical care because of palpitations, breathlessness and the feeling of near syncope. She complained of dyspnea on moderate exertion and slight lower limbs edema during the last week. She also reported a significant increase in the menstrual flow, with large amounts of blood clots, what was out of her regular menses. She had been prescribed intramuscular progesterone every three months for the last two years as the contraceptive method, receiving the last dose seven months ago. Patient denied having noted any other bleeding site. She did not present any comorbidity, drug allergies, smoking or alcohol consumption. She had an obstetric history of five pregnancies, one of them a twin gestation, five vaginal deliveries. She did not follow adequate prenatal care in any of the five pregnancies. She has been recently diagnosed with anemia when it was prescribed oral iron supplementation. The physical examination showed a pale, hydrated, anicteric, afebrile $\left(T=37.1^{\circ} \mathrm{C}\right)$ patient. The respiratory rate was $16 \mathrm{rmpm}$, pulse oxymetry $=98 \%$, heart rate $=90 \mathrm{bpm}$ with symmetrical and rhythmic pulse, blood pressure $=115 \times 60 \mathrm{mmHg}$. There were no clinical signs of heart failure. On cardiac auscultation, a systolic murmur in the mitral area was evidenced. Lung and abdominal examination

\footnotetext{
a Department of Internal Medicine - Hospital Universitário, Universidade de São Paulo, São Paulo/SP - Brazil.

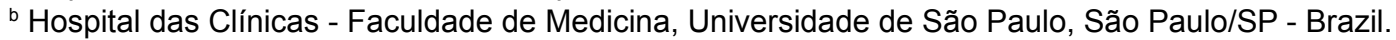

${ }^{c}$ Anatomic Pathology Service - Hospital Universitário, Universidade de São Paulo, São Paulo/SP - Brazil.
} 
were unremarkable. Laboratory tests are listed in Table 1 and 2. Ascaris lumbricoides was detected in a stool test.

The bimanual gynecological examination was painless while evaluating the adnexa as well as mobilization of the cervix. The uterus was retroverted and twofold increased in size. The specular examination revealed neither bleeding discharge from the cervix nor any free fluid collected in the cul-de-sac. The transvaginal ultrasonography showed an increased uterine volume $254 \mathrm{~cm}^{3}$ (normal range $=180 \mathrm{~cm}^{3}$ ) with an echogenic mass in the inner lining of the uterus, measuring $5.2 \times 3.6 \times 2.9 \mathrm{~cm}$, comprising blood vessels in its interior, which could correspond to a polyp. Urinary pregnancy test (total human chorionic gonadotropin) was negative. The patient was treated with red blood cells transfusion and albendazole $400 \mathrm{mg}$ single dose. During the hospital stay, she restarted the genital bleeding which dropped the hemoglobin level to $5.4 \mathrm{~g} \cdot \mathrm{dL}^{-1}$. A surgical approach was attempted. Hysteroscopy was performed showing an irregular endometrial cavity with a polypoid formation on the anterior wall and a sessile mass on the fundus. The tubal ostia could not be visualized. Curettage product revealed a moderate amount of friable, amorphous and fetid material. The curettage was immediately followed by an uncontrolled heavy bleeding which ensued a severe hypotension. A total abdominal hysterectomy was undertaken allowing clinical stabilization. The surgical specimen examination showed a sessile, friable and fetid mass adherent to the myometrium (Figure 1). Pathological examination detected a fragment of partially necrotic placenta accreta measuring $3.0 \mathrm{~cm}$ in the greatest diameter in the uterine fundus, consistent with a hyalinized placental polyp. The histology of the polyp was composed primarily of necrotic and hyalinized placental chorionic villi, but also of areas with preserved trophoblast, which penetrated superficially the myometrium (accretism). An acute polymorphonuclear inflammatory infiltrate and areas of hemorrhage with fibrin were observed along with necrotic areas. The surrounding endometrium showed chronic inflammatory infiltrate with plasma cells and granulation tissue (Figure 2).

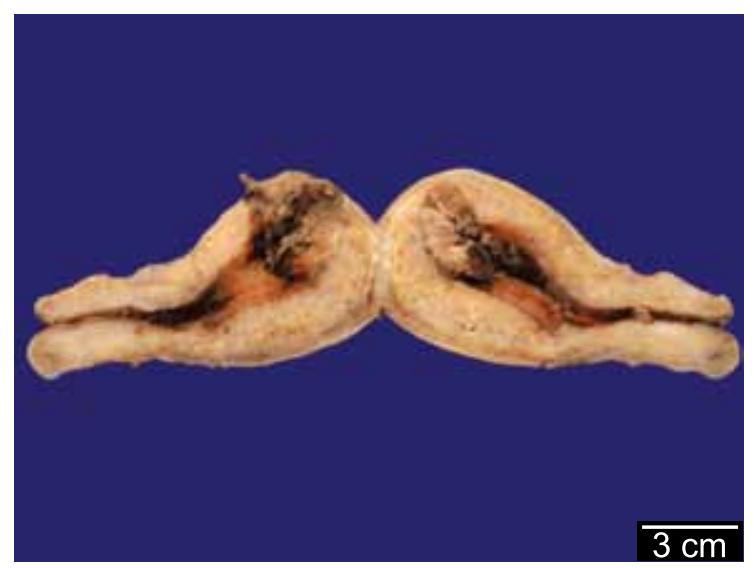

Figure 1 - Longitudinal section of formalinfixed uterus, showing a $3.0 \mathrm{~cm}$ polypoid mass at the fundus. Observe a thickened myometrium compatible with multiparity.

Table 1 - Laboratory tests

\begin{tabular}{|c|c|c|c|c|c|c|c|}
\hline & Do & D5 & VR & & Do & D5 & VR \\
\hline Hemoglobin & 4,8 & 3,9 & $12,3-15,3 \mathrm{~g} \%$ & PT & & 91 & $70-100 \%$ \\
\hline Hematocrit & 15 & 13 & $36,0-45,0 \%$ & APTT & & 0,99 & $<1,25$ \\
\hline MCV & 78 & 77 & $80-96 \mathrm{fL}$ & & & & \\
\hline $\mathrm{MCH}$ & 26 & 24 & $27,5-33,2 \mathrm{pg}$ & BUN & 6 & 13 & $5-25 \mathrm{mg} \cdot \mathrm{dL}^{-1}$ \\
\hline RDW & 15,6 & 17,7 & $11-16 \%$ & Creatinine & 0,7 & & $0,4-1,3 \mathrm{mg} \cdot \mathrm{dL}^{-1}$ \\
\hline Leucocytes & 16.200 & 11,900 & $4,4-11,310^{3} / \mathrm{mm}^{3}$ & & & & \\
\hline Mielocytes & 1 & 0 & $0 \%$ & Sodium & 136 & 134 & $136-146 \mathrm{mEq} \cdot \mathrm{L}^{-1}$ \\
\hline Rods & 7 & 2 & $1-5 \%$ & Potassium & 3,9 & 4,5 & 3,5-5,0 mEq. $\mathrm{L}^{-1}$ \\
\hline Segmented & 75 & 70 & $45-70 \%$ & Total bilir & 0,17 & & $0,3-1,2 \mathrm{mg} \cdot \mathrm{dL}^{-1}$ \\
\hline Eosinophils & 0 & 1 & $1-4 \%$ & ALT & 16 & & $9-36 \cup . L^{-1}$ \\
\hline Basophils & 0 & 0 & $0-2,5 \%$ & AST & 21 & & 10-31 U.L-1 \\
\hline Linfocytes & 7 & 0 & $18-40 \%$ & LDH & 142 & & $120-246$ U.L-1 \\
\hline Monocytes & 5 & 4 & $2-9 \%$ & Glucose & 96 & & $70-99 \mathrm{mg} \cdot \mathrm{dL}^{-1}$ \\
\hline Platelets & $380.10^{3}$ & $499.10^{3}$ & $150-40010^{3} / \mathrm{mm}^{3}$ & TSH & 0,9 & & 0,55-4,78 mcUl.mL $\mathrm{m}^{-1}$ \\
\hline
\end{tabular}

D0 = admission Day, D5 = fifth hospital Day, MCV = mean cospuscular volume, $\mathrm{MCH}=$ mean corpuscular hemoglobin, RDW = red cell distribution width, $\mathrm{PT}=$ prothrombin time, $\mathrm{APTT}=$ activated partial thromboplastin time, $\mathrm{BUN}=$ blood urea nitrogen, $\mathrm{ALT}=$ alanine aminotranspherase, $\mathrm{AST}=$ aspartate aminotranspharese, $\mathrm{LDH}=$ lactate dehydrogenase, $\mathrm{TSH}=$ thyroid stimulating hormone. 

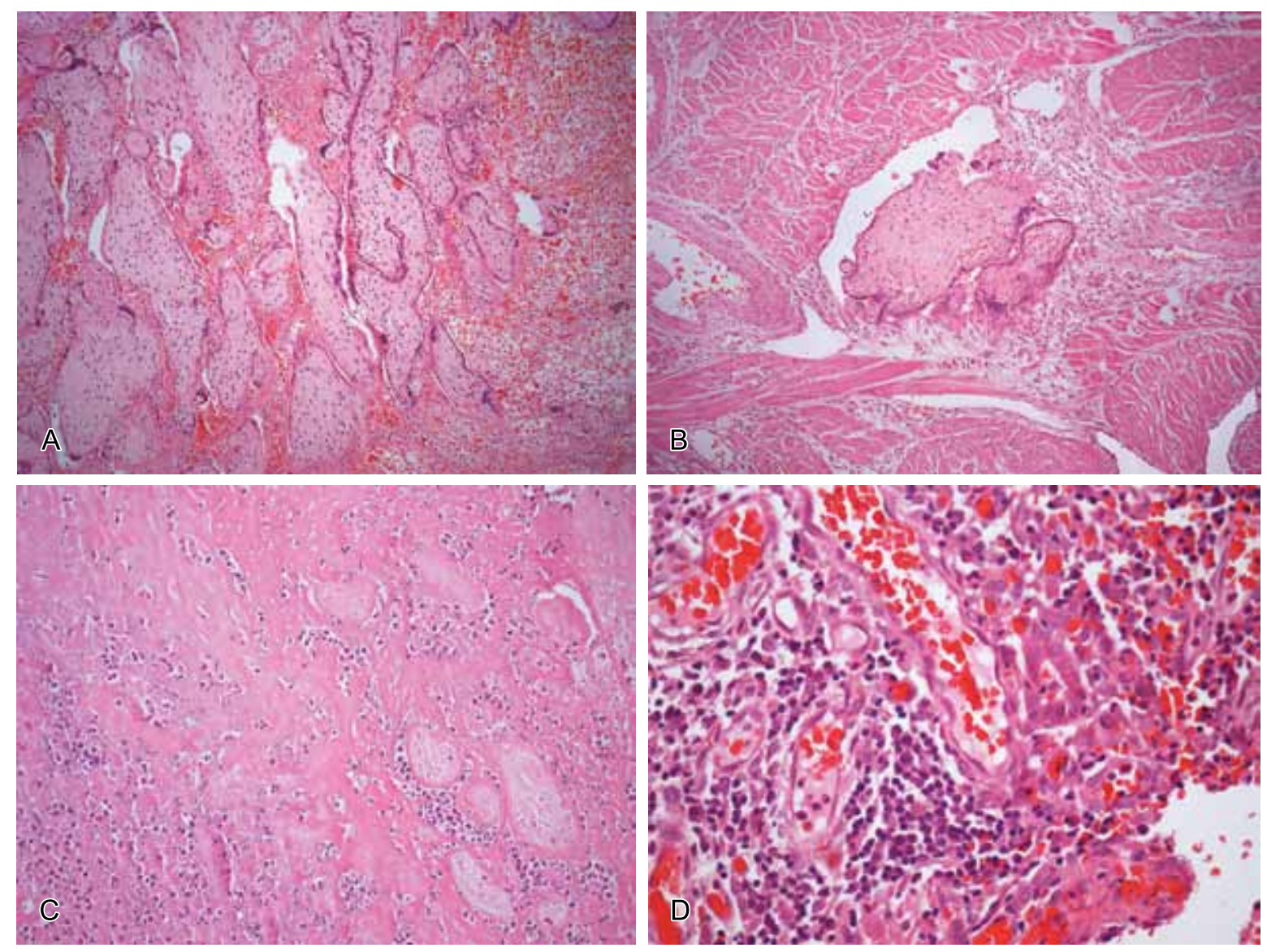

Figure 2 - Photomicrographs of the placental polyp: A - (HE-100x) placental villous with central fibrosis and hemorrhagic areas on the right; $\mathbf{B}$ - (HE-100x) detail of accretism with villi penetrating directly through the myometrium, without interposition of decidua; C - (HE-200x) area of necrotic villi with acute polymorphonuclear inflammatory infiltrate; D - (HE-400x) surrounding endometrium with lymphoplasmacytic inflammatory infiltrate and proliferation of capillaries.

Table 2 - Iron metabolism tests and reticulocytes

\begin{tabular}{ccc}
\hline & & VR \\
\hline Serum iron & 6 & $37-145 \mathrm{mcg} \cdot \mathrm{dL}^{-1}$ \\
Transferrin & 291 & $250-410 \mathrm{mcg} \cdot \mathrm{dL}^{-1}$ \\
Ferritin & 68 & $10-291 \mathrm{ng} \cdot \mathrm{mL}^{-1}$ \\
Saturation of transferrin & 2 & $20-50 \%$ \\
Reticulocytes & 50,000 & $24,000-84,000 / \mathrm{mm}^{3}$ \\
\hline
\end{tabular}

Serum HCG was retrospectively dosed in a frozen stored sample resulted in $184.7 \mathrm{mUI} . \mathrm{mL}^{-1}$ (normal range $=<10 \mathrm{mUl} \cdot \mathrm{mL}^{-1}$ ). The postoperative period was uneventful and the patient was discharged on the third postoperative day.

\section{DISCUSSION}

Placental polyps are defined as pedunculated or polypoid fragments of placenta or ovular membranes retained for an indefinite period of time into the uterus after abortion or child birth.

Baer was the first to recognize this condition in 1884 and since then some cases have been reported in the literature. ${ }^{1-5}$ Polyps can arise from placenta accreta, gestational trophoblastic disease and choriocarcinoma. An important cause of retained placenta is the accretism which consists in the abnormal adherence of the placenta into the uterine wall. It is believed that uterine atony combined with placenta accreta contributes to placental polyps development. ${ }^{1,6}$

The disease is classified according to the depth of trophoblastic tissue invasion, which can be superficial in the myometrium (placenta accreta) invade the myometrium in depth (placenta increta) or penetrate to or through the uterine serosa with or without invasion of the surrounding organs (placenta percreta). ${ }^{7}$ 
About $80 \%$ of cases of placental polyps derived from placenta accreta, ${ }^{8}$ as in the present case report. There are numerous risk factors for placenta accreta and its incidence has been increasing in recent decades. The most important risk factor for placenta accreta is the placenta previa associated with the presence of uterine scar derived from myomectomy, cesarean deliveries and curettage..$^{9,10}$ Maternal age, multiparity, smoking during pregnancy, hypertension during pregnancy, endometrial defects are other risk factors. ${ }^{9,11-13}$

The clinical picture of placenta accreta usually involves massive hemorrhage in the immediate postpartum and may lead to hypovolemic shock and death, usually demanding interventions that range from curettage to total hysterectomy. Other complications are the invasion of organs like the bladder, ureters, and neurovascular structures, consumptive coagulopathy, adult respiratory distress syndrome, renal failure, infection and thromboembolism. ${ }^{14,15}$ Usually, the clinical suspicion of placenta accreta is made by the ultrasonographic examination performed during the second or third trimester of the prenatal period. The findings, in ultrasound examination, associated with placenta accreta are: loss of the hypoechoic image in the retro placental area, the presence of many round and linear vascular lacunae which produce a "motheaten" appearance to the placenta, placental tissue or blood vessels crossing the uterus placental border; reduced myometrium thickness (less than $1 \mathrm{~mm}$ ) and the presence of lacunae that exhibit marked turbulent blood flow by color doppler scanning. ${ }^{16-18}$ In chronic cases, the placental retention usually does not cause massive bleeding immediately after child birth, which indeed makes the diagnosis very difficult. Chronic cases are scarce in the literature and are characterized by pelvic pain; mild or moderate bleeding in the postpartum that may require some medical intervention ${ }^{19}$ and puerperal infections.

The time for diagnosis is extremely varied ranging from days to years after delivery or abortion. In the case reported here, as some others in the literature, total human chorionic gonadotropin (HCG) was detected in the blood in low level, suggesting that the polyp can maintain placental endocrine activity with gestational cytoplasmics markers. ${ }^{20}$ The placental membranes are normally reabsorbed by macrophages and leukocyte degranulation in the affected area. ${ }^{21}$ During the menstrual cycle there is a marked neutrophil infiltration into the endometrial tissue, mediated by interleukin 8 (IL-8), their degranulation takes part in the endometrial sloughing. ${ }^{22}$ It is reported that chorionic cells synthesize and release IL-8, being inhibited by the administration of medroxyprogesterone acetate, ${ }^{22}$ what could explain the retaining of placental tissue observed in the present case, where this hormone has been prescribed after her last child-birth.

It is known that iron deficiency is the most prevalent nutritional scarcity in less-favored social classes. Thus, the first hypothesis to explain the detected iron-deficiency anemia was attributed to low food intake as well as by multiparity and lack of medical follow-up, which are significant causes of iron depletion. ${ }^{23-26}$ Excessive menstrual bleeding is another cause of anemia in women during menacme ${ }^{27-29}$ and it was also taken in account because of the recent change in the patient's menstrual pattern. Adult women have less storage iron, depending upon the extent of menses, pregnancies, deliveries, lactation, and iron intake. The perception about the menstrual cycle may be variable ${ }^{29,30}$ explaining the chronic iron deficiency in women without gynecologic complaints. In the case reported here we hypothesized that the patient did not realize how intense her menstrual bleedings were. Moreover, she has never followed prenatal care or any regular consultation, despite the multiparity and lactation. Only when the symptoms of anemia caused restrictions in her daily activities, she sought medical attention, otherwise she would probably neglect the menstrual pattern change.

For this reason, we call attention for gynecological, nutritional and social evaluation in the setting of an iron-deficiency anemia.

\section{ACKNOWLEDGEMENTS}

We are grateful to Rosa Maria C. Zanardi for the technical support on the visual work.

\section{REFERENCES}

1. Dyer I, Bradburn DM. An inquiry into the etiology of placental polyp. Am J Obst Gynecol. 1971; 109:858-67. PMid:5313723.

2. Hagstrom HT. Late puerperal hemorrhages due to placental polyp. Am J Obst Gynecol. 1940; 39:879-81. 
3. Kurtz GR, Comando EN. Tree cases of late puerperal hemorrhages caused by placental polyp. Am J Obst Gynecol. 1953; 66:663-7. PMid:13080360.

4. Swan RW, Woodruff JD. Retained products of conception: histologic viability of placental polyps. Obst Gynecol. 1969; 34:506-14. PMid:4309817.

5. Baer BF. Placental polypus which simulated malignant disease of the uterus. Philadelphia Med Times. 1884; 15:175.

6. Hoberman LK, Hawkinson JA, Beecham CT. Placental polyps: report of three cases. Obst Gynecol. 1963; 22:259. PMid:13954878.

7. Bauer ST, Bonanno C. Abnormal placentation. Semin Perinatol. 2009;33:88-96. PMid:19324237. http://dx.doi. org/10.1053/j.semperi.2008.12.003

8. Belfort, MA. Placental accreta. Am J Obst Gynecol. 2010; 203:430-9. PMid:21055510. http://dx.doi. org/10.1016/j.ajog.2010.09.013

9. Clark SL, Koonings PP, Phelan JP. Placenta previa/accreta and prior cesarian ressection. Obst Gynecol.1985; 66.89-92.

10. Usta IM, Hobeika EM, Musa AA, Gabriel GE, Nassar AH. Placenta previa-accreta: risk factors and complications. Am J Obst Gynecol. 2005; 193:1045-9. PMid:16157109. http://dx.doi.org/10.1016/j.ajog.2005.06.037

11. Wu S, Kocherginsky M, Hibbard JU. Abnormal placentation: twenty year analysis. Am Obst Gynecol. 2005; 192:1458-61. PMid:15902137. http://dx.doi.org/10.1016/j.ajog.2004.12.074

12. Miller DA, Chollet JA, Goodwin TM. Clinical risk factors for placenta previa/placenta accreta. Am J Obst Gynecol. 1997; 177:210-4. http://dx.doi.org/10.1016/ S0002-9378(97)70463-0

13. Gielchinsky Y, Mankuta D, Rojansky N, Laufer N, Gielchinsky I, Ezra Y. Perinatal outcome of pregnancies complicated by placenta acreta. Obst Gyneol. 2004; 104:527-30. http:// dx.doi.org/10.1097/01.AOG.0000136084.92846.95

14. Washecka R, Behling A. Urologic complications of placenta percreta invading the urinary bladder: a case report and review of the literature. Hawaii Med J. 2002; 61:66-9. PMid:12050959.

15. O'Brien JM, Barton JR, Donaldson ES. The management of placenta percreta: conservative and operative strategies. Am J Obst Gynecol. 1996; 175:1632-8. http://dx.doi. org/10.1016/S0002-9378(96)70117-5

16. Twickler DM, Lucas MJ, Balis AB, et al. Color flow mapping for myometrial invasion in woman with a pior cesarian delivery. J Matern Fetal Med. 2000; 9:330-5. http://dx.doi. org/10.1002/1520-6661(200011/12)9:6\%3C330::AIDMFM1002\%3E3.0.CO;2-O

17. Levine D, Hulka CA, Ludmir J, Li W, Edelman R. R: placenta accreta: evaluation with color doppler US, power Doppler US and MR imaging. Radiology. 1997; 205:773-6. PMid:9393534.
18. Comstock $\mathrm{CH}$, Love Junior JJ, Bronsteen RA, et al. Sonographic detection of placenta accreta in the second and third trimestres of pregnancy. Am J Obstet Gynecol. 2004; 190:1135-40. PMid:15118654. http://dx.doi. org/10.1016/j.ajog.2003.11.024

19. Takeda A, Koyama K, Imoto S, Mori M, Sakai K, Nakamura $H$. Placental polyp with prominent neovascularization. Fertil Steril. 2010; 93:1324-6. PMid:19394597. http://dx.doi. org/10.1016/j.fertnstert.2009.03.065

20. Lawrence WD, Qureshi F, Bonakdar MI. "Placental polyp": light microscopic and immunohistochemical observations. Hum Pathol. 1988; 19:1467-70. http://dx.doi.org/10.1016/ S0046-8177(88)80243-0

21. Kelly RW, Illingworth P, Baldie G, Leask R, Brouwer S, Calder AA. Progesterone control of interleukin-8 production in endometrium and chorio-decidual cells underlines the role of the neutrophil in menstruation and parturition. Hum Reprod. 1994; 9:253-8. PMid:8027281.

22. Lockwood CJ, Kumar P, Krikun G, et al. Effects of thrombin, hypoxia, and steroids on interleukin-8 expression in decidualized human endometrial stromal cells: implications for long-term progestin-only contraceptive-induced bleeding. J Clin Endocrinol Metab. 2004; 89:1467-75. http://dx.doi. org/10.1210/jc.2003-030141

23. Schumann K, Elsenhans B, Maurer A. Iron suplementation. J Trace Elem Med Biol.1998; 2:129-40. http://dx.doi. org/10.1016/S0946-672X(98)80001-1

24. Adish AA, Esrey SA, Gyorkos TW, Johns T. Risk factors for iron deficiency anaemia en preschool children in northern Ethiopia. Public Health Nutr. 1999; 2:243-52. http://dx.doi. org/10.1017/S1368980099000336

25. Singh K, Fong YF, Arulkumaran S. Anaemia in pregnancy - a cross-sectional study in Singapore. Eur J Clin Nutr. 1998; 52:65-70. PMid:9481535. http://dx.doi.org/10.1038/ sj.ejcn. 1600517

26. Van Der Broek NR, Letsky EA, White SA, Skenkin A. Iron status in pregnant women: which measurements are valid? Br J Haematol. 1998; 103:817-24. PMid:9858238. http:// dx.doi.org/10.1046/j.1365-2141.1998.01035.x

27. Puolakka J, Janne O, Pakarinem A, Vihko R. Serum ferritin in the diagnosis of anemia during pregnancy. Acta Obst Gynecol Scand Suppl. 1980; 95:57-63. http://dx.doi. org/10.3109/00016348009156381

28. Taylor DJ, Mallen C, McDougall N, Lind T. Effect of iron supplementation on serum ferritin levels during and after pregnancy. Br J Obst Gynaecol. 1982; 89:1011-7. http:// dx.doi.org/10.1111/j.1471-0528.1982.tb04656.x

29. Kepczyk T, Cremings JE, Long BD, Bachinki MB, Smith LR, McNally PR. A prospective, multidisciplinar evaluetion of premenopausal woman with iron deficiency anemia. Am J Gastroenterol. 1999; 94:109-15. PMid:9934740. http:// dx.doi.org/10.1111/j.1572-0241.1999.00780.x

30. Bothwell TH, Charlton RW. Iron deficiency in Women: a report of. Washington. New York: Nutrition Foundation; 1981. 


\section{Conflict of interest: None}

Submitted on: $5^{\text {th }}$ November 2011

Accept on: $14^{\text {th }}$ November 2011

Correspondence: Divisão de Clínica Médica

Av. Prof. Lineu Prestes, 2565 - Cidade Universitária - São Paulo/SP - Brazil

CEP: 05508-000 - Phone: +55 (11) 3091-9200

E-mail: ffcampos@usp.br 